\title{
Ropivacaine has no advantage over bupivacaine in thoracic epidural analgesia for patients with pectus excavatum undergoing the Nuss procedure - a single blind randomized clinical trial comparing efficacy and safety
}

\author{
Małgorzata Walaszczyk ${ }^{1}$, Rafał Wiench ${ }^{2}$, Maja Copik ${ }^{1}$, Jacek Karpe ${ }^{1}$, Małgorzata Łowicka ${ }^{3}$, Anna Pióro ${ }^{3}$, Piotr Knapik ${ }^{3}$, \\ Hanna Misiołek ${ }^{1}$ \\ ${ }^{1}$ Department of Anesthesiology and Intensive Therapy, Medical University of Silesia, Zabrze, Poland \\ ${ }^{2}$ Department of Conservative Dentistry with Endodontics, Medical University of Silesia, Zabrze, Poland \\ ${ }^{3}$ Department of Cardiac Anesthesia and Intensive Therapy, Medical University of Silesia, Zabrze, Poland
}

Kardiochirurgia i Torakochirurgia Polska 2018; 15 (1): 5-9

\begin{abstract}
Introduction: Pectus excavatum repair (Nuss procedure) is a painful procedure requiring effective postoperative analgesia. Aim: To establish whether thoracic epidural analgesia with ropivacaine is non-inferior to epidural analgesia with bupivacaine following the Nuss procedure in children.

Material and methods: The prospective, randomized, controlled, single blind study included 81 children. Computergenerated random numbers were used to allocate treatment. All children received general anesthesia. Intraoperative and postoperative analgesia was achieved with either $0.5 \%$ and $0.1 \%$ ropivacaine (group $\mathrm{R}$ ) or $0.375 \%$ and $0.0625 \%$ bupivacaine (group B). The Numeric Rating Scale (NRS) and the Prince Henry Hospital Pain Score (PHHPS) were used to assess postoperative pain directly after and 1, 8, 20 and 24 hours after awakening from general anesthesia. NRS scores of more than 2 and a PHHPS score of more than 1 were considered as pain requiring intervention. Hemodynamic stability and side effects were also compared between the groups.

Results: The durations of the procedure and extubation times in groups $R$ and $B$ were similar ( $59 \pm 7$ vs. $56 \pm 10$ minutes and $9 \pm 5$ vs. $10 \pm 5$ minutes, respectively). Pain scores requiring intervention were below $10 \%$ and were recorded with similar frequency in both groups, except for one difference in the PHHPS score in favor of group R after 24 hours ( $12 \%$ vs. $40 \%, p<0.05)$. The frequency of side effects and hemodynamic stability were similar in both groups.

Conclusions: $0.1 \%$ epidural ropivacaine has no advantage over $0.0625 \%$ epidural bupivacaine for pectus excavatum repair in children.
\end{abstract}

Key words: ropivacaine, bupivacaine, thoracic epidural, Nuss procedure.

\section{Streszczenie}

Wstęp: Rekonstrukcja klatki szewskiej (operacja Nussa) jest bolesną procedurą, która wymaga skutecznej analgezji pooperacyjnej. Cel: Wykazanie, czy analgezja zewnątrzoponowa u dzieci po zabiegu Nussa z użyciem ropiwakainy jest równoważna (non-inferiority) z analgezją z użyciem bupiwakainy.

Materiat i metody: Do prospektywnego, randomizowanego badania kontrolnego, z pojedynczym zaślepieniem włączono 81 dzieci. Przydział do poszczególnych grup odbył się z użyciem alokacji komputerowej. Zabieg został wykonany w znieczuleniu ogólnym złożonym, dodatkowo u wszystkich dzieci zapewniono analgezję zewnątrzoponową (śród- i pooperacyjnie) z zastosowaniem $0,5 \%$ oraz 0,1\% ropiwakainy (grupa $\mathrm{R}$ ) lub 0,375\% oraz $0,0625 \%$ bupiwakainy (grupa B). Ból pooperacyjny oceniano bezpośrednio po wybudzeniu oraz w 1., 8., 20. i 24. godzinie, stosując Numeryczną skalę bólu (NRS) oraz Skalę bólu Prince Henry Hospital (PHHPS). Ból w skali NRS większy niż 2 oraz PHHPS większy niż 1 oceniano jako wymagający interwencji. Porównywano również wpływ na układ krążenia oraz skutki uboczne w obu grupach.

Wyniki: Czas trwania operacji oraz czas ekstubacji były porównywalne w grupie R i grupie B ( $59 \pm 7$ vs $56 \pm 10$ min i $9 \pm 5$ vs $10 \pm 5 \mathrm{~min}$, odpowiednio). Odsetek zarejestrowanego bólu wymagającego dodatkowej interwencji w obu grupach był podobny i wynosił poniżej 10\%, z wyjątkiem bólu ocenianego w 24. godzinie po ekstuabcji w skali PHHPS na korzyść grupy R $(12 \%$ vs $40 \%, p<0,05)$. Częstość występowania skutków ubocznych oraz wpływ na układ krążenia były podobne.

Wnioski: Skuteczność analgezji zewnątrzoponowej po zabiegu Nussa u dzieci z użyciem 0,1\% ropiwakainy jest porównywalna z zastosowaniem 0,0625\% bupiwakainy.

Stowa kluczowe: ropiwakaina, bupiwakaina, znieczulenie zewnątrzoponowe piersiowe, operacja Nussa. 


\section{Introduction}

Funnel chest (pectus excavatum) is the most common congenital anomaly of the anterior chest wall [1-3]. The estimated prevalence in the general population is approximately $2 \%$, of which $0.5 \%$ require surgical correction. The most recent method of pectus excavatum repair was introduced in 1997 by Donald Nuss (minimally invasive repair of pectus excavatum - MIRPE). The operation involves lifting the sternum with a specially modeled stainless steel bar, which is inserted under thoracoscopic guidance through two separate lateral incisions of 3-4 cm [4]. According to the original protocol proposed by Nuss, this operation should be carried out under general anesthesia with endotracheal intubation. The use of epidural analgesia intra- and postoperatively is highly effective and provides superior pain control [5-7]. The procedure is extremely painful, and therefore postoperative pain management in the first 72 hours is a challenge [8].

Although bupivacaine still remains a standard local anesthetic, it is increasingly replaced with ropivacaine due to its lower toxicity for the circulatory and nervous system and less profound subsequent motor blockade [9, 10]. These advantages of ropivacaine may be particularly important in children. With the use of identical concentrations, ropivacaine is considered to be less potent than bupivacaine, and thus equipotent concentrations are usually higher [9]. Moreover, research on the minimum local anesthetic concentration (MLAC), carried out in recent years, revealed that the potency of local analgesics is relative; hence it is very difficult to directly apply the results of research on the optimal values of MLAC to everyday clinical practice. Additionally, MLAC values significantly decrease when an opioid is added to epidural anesthesia [11].

There are not many published studies on postoperative analgesia following the Nuss procedure. They include our previous study on the use of epidural and opioid analgesia in this indication [12]. Furthermore, there are no data on the usefulness of ropivacaine in such conditions.

\section{Aim}

Therefore, the aim of this study was to establish whether thoracic epidural analgesia with ropivacaine is non-inferior to thoracic analgesia with bupivacaine following the Nuss procedure in children.

\section{Material and methods}

This prospective, randomized, single blind study was conducted in a university hospital. Eighty-one children aged 11-18 years (mean: $15.5 \pm 2.0$ years) who underwent elective pectus excavatum repair participated in the study. The operation was performed according to the original protocol of Donald Nuss without the use of a metal rib stabilizer. Clinical causes as well as psychological and cosmetic aspects were indications for surgery.

The design of the study was approved by the Local Ethics Committee (approval number: NN-013-86/02). Informed parental consent was obtained for participation in the study. Additionally, separate consent was required to perform epidural analgesia. Children whose parents did not give their consent to the insertion of the epidural catheter were anaesthetized using standard balanced anesthesia with opioids and postoperative analgesia was achieved with subcutaneous morphine combined with non-opioid analgesic drugs. These patients were excluded from the study. Patients whose parents consented to epidural analgesia were scheduled to receive either epidural ropivacaine (Naropin, Astra Zeneca, USA; Group R) or bupivacaine (Marcaine Spinal 0.5\% Heavy, Astra Zeneca AB, Sweden; Group B). The selection of patients for each group was random, based on a computer-generated list.

Oral midazolam (Dormicum, Roche, France) was given as a premedication one hour prior to arrival at the anesthetic room. The epidural catheter was inserted under local anesthesia before the induction of anesthesia. A test dose containing $20 \%$ of the induction dose of the local anesthetic was administered to confirm the correct position of the epidural catheter. If no symptoms of spinal anesthesia were observed, anesthesia was induced with propofol (Diprivan, Astra Zeneca, UK), and maintained further by either propofol infusion or sevoflurane (Sevorane, Abbott Laboratories, USA). Muscle relaxation during anesthesia was achieved through administration of repeated doses of vecuronium (Norcuron, Organon Teknika, The Netherlands).

During the insertion of the epidural catheter, we primarily aimed to approach the Th6-Th7 interspace. In cases of failure, adjacent levels in the epidural space were approached. For intraoperative analgesia, a mixture of $0.5 \%$ ropivacaine (group $\mathrm{R}$ ) or $0.375 \%$ bupivacaine (group B) was used, both combined with adrenaline in a $1: 200000$ solution and $7.5 \mu \mathrm{g} / \mathrm{ml}$ fentanyl.

Sensory blockade of seven spinal segments was required to provide sufficient analgesia. The volume of the induction dose was calculated, providing $0.8 \mathrm{ml}$ of local anesthetic per segment. Additionally, we added (or subtracted) $0.05 \mathrm{ml}$ per segment for each $5 \mathrm{~cm}$ of height above (or below) $150 \mathrm{~cm}$. If the epidural space could not be reached directly towards the most prominent deformity, the dose was increased to achieve a blockade of eight spinal segments. Paracetamol (Perfalgan, BMS, New Zealand) 30 mg/kg was also administered intravenously in both groups directly after induction of anesthesia.

Intraoperative analgesia was achieved with ropivacaine (group R) or bupivacaine (group B). The infusion of the local anesthetic in both groups was initiated 1 hour after the administration of the loading dose and was maintained throughout the operation at a rate of $0.8 \mathrm{ml} / \mathrm{segment} /$ hour. The rate was increased or decreased by $0.05 \mathrm{ml} / \mathrm{segment} /$ hour for each $5 \mathrm{~cm}$ of height over or under $150 \mathrm{~cm}$. Postoperative analgesia was achieved with an epidural infusion of either $0.1 \%$ ropivacaine or $0.0625 \%$ bupivacaine, in both cases mixed with $6 \mu \mathrm{g} / \mathrm{ml}$ fentanyl. The infusion rate was initially identical to the rate used for intraoperative analgesia, with the postoperative concentration reduced to $20 \%$ of the intraoperative concentration for both local anesthetics. 
The Numeric Rating Scale (NRS) and the Prince Henry Hospital Pain Score (PHHPS) were used to assess postoperative analgesia. If postoperative pain achieved 3 points on the NRS scale and/or 2 points on the PHHPS scale, the patients were given $10 \mathrm{mg} / \mathrm{kg}$ intravenous paracetamol. In cases of persistent lack of sufficient analgesia (defined as 2 points on the NRS scale and/or 1 point on the PHHPS scale), administration of opioids (subcutaneous morphine) was planned. Epidural analgesia was administered for 3 postoperative days.

Heart rate, systolic blood pressure, depth of sedation and pain scores (NRS and PHHPS) were registered directly after awakening and 1, 8, 20 and 24 hours after awakening from general anesthesia. Side effects and the use of additional medications were also registered. NRS scores of more than 2 and/or a PHHPS score of more than 1 were considered as pain requiring intervention.

\section{Statistical analysis}

Postoperative pain scores, hemodynamic parameters, need for additional analgesia and side effects (postoperative nausea and vomiting - PONV) in the postoperative period were assessed. The data were compared using ANOVA with the Tukey post-hoc test. Ranked quantitative data were compared with the Mann-Whitney test. Nominal data were compared with the $\chi^{2}$ test (with the Yates correction if necessary). $P$-values below 0.05 were considered statistically significant.

\section{Results}

The children's demographic data, spirometry, initial hemodynamics and oxygenation were similar in both groups (Table I). Overall, epidural catheters were inserted in the most appropriate interspace (Th6-Th7 level) in only 59 out of the 81 (73\%) studied children; however, the distribution of other locations did not differ significantly between the two groups. The durations of the procedure and extubation times in groups R and B were similar ( $59 \pm 7$ vs. $56 \pm 10$ minutes and $9 \pm 5$ vs. $10 \pm 5$ minutes, respectively).

An increased infusion rate with subsequent paracetamol administration (according to the study protocol) was required in 1 patient in group $R$ and in 9 patients in group $B$ $(p<0.01)$, despite the fact that the epidural catheter was inserted in the most optimal intervertebral space in a similar number of children (11 in group R and 12 in group B). Pain scores requiring intervention, however, were recorded with similar frequency, except for one difference 24 hours postawakening in favor of group R (Table II). No patients in either group required opioids.

Heart rate and systolic blood pressure values were not significantly different throughout the postoperative period (Fig. 1). The occurrence of side effects was similar in both groups (Table III).

\section{Discussion}

The Nuss procedure by definition is a minimally invasive surgical technique. The repair of pectus excavatum
Table I. Demographic and baseline clinical data

\begin{tabular}{|c|c|c|c|}
\hline \multicolumn{2}{|c|}{ Parameter } & $\begin{array}{c}\text { Group } \mathrm{R}(n=41) \\
\text { Mean value } \pm \text { SD }\end{array}$ & $\begin{array}{l}\text { Group B }(n=40) \\
\text { Mean value } \pm \text { SD }\end{array}$ \\
\hline \multicolumn{2}{|c|}{ Age [years] } & $15.6 \pm 1.9$ & $15.9 \pm 1.6$ \\
\hline \multicolumn{2}{|c|}{ Height $[\mathrm{cm}]$} & $174 \pm 13$ & $171 \pm 10$ \\
\hline \multicolumn{2}{|c|}{ Body weight [kg] } & $54.3 \pm 10.0$ & $53.4 \pm 9.4$ \\
\hline \multicolumn{2}{|c|}{ BMI $\left[\mathrm{kg} / \mathrm{m}^{2}\right]$} & $18.4 \pm 1.8$ & $17.9 \pm 2.5$ \\
\hline \multicolumn{2}{|c|}{ Haller index } & $3.4 \pm 0.8$ & $3.5 \pm 0.6$ \\
\hline \multicolumn{2}{|c|}{ Female sex, $n(\%)$} & $9(22)$ & $10(25)$ \\
\hline \multicolumn{2}{|c|}{ Male sex, $n(\%)$} & $32(78)$ & $30(75)$ \\
\hline \multirow{4}{*}{ 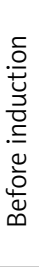 } & Heart rate [bpm] & $78.5 \pm 12.4$ & $80.2 \pm 11.8$ \\
\hline & $\begin{array}{l}\text { Systolic pressure } \\
{[\mathrm{mm} \mathrm{Hg}]}\end{array}$ & $118 \pm 15$ & $121 \pm 16$ \\
\hline & $\begin{array}{l}\text { Diastolic pressure } \\
{[\mathrm{mm} \mathrm{Hg}]}\end{array}$ & $76.2 \pm 6.6$ & $82.4 \pm 6.8$ \\
\hline & Oxygen saturation (\%) & $96.6 \pm 1.2$ & $97.4 \pm 1.6$ \\
\hline \multirow{2}{*}{$\begin{array}{l}\text { ASA status, } \\
n(\%)\end{array}$} & A status, I & $25(55)$ & $26(60)$ \\
\hline & II & $16(45)$ & $14(40)$ \\
\hline \multirow{2}{*}{$\begin{array}{l}\text { Number of } \\
\text { bars, } n(\%)\end{array}$} & mber of Single & $30(80)$ & $32(75)$ \\
\hline & S, Double & $11(20)$ & $8(25)$ \\
\hline
\end{tabular}

$n$ - number of patients, SD - standard deviation, bpm - beats per minute.

Table II. Number and percentage of patients with NRS $>2$ and PHHPS $>1$

\begin{tabular}{lcc}
$\begin{array}{l}\text { Postoperative } \\
\text { hour }\end{array}$ & $\begin{array}{c}\text { Group R }(n=41) \\
n(\%)\end{array}$ & $\begin{array}{c}\text { Group B }(n=40) \\
\text { NRS }>2:\end{array}$ \\
\hline $0 \mathrm{~h}$ & $0(0)$ & $0(0)$ \\
\hline $1 \mathrm{~h}$ & $0(0)$ & $0(0)$ \\
\hline $8 \mathrm{~h}$ & $2(5)$ & $4(10)$ \\
\hline $20 \mathrm{~h}$ & $1(2)$ & $6(15)$ \\
\hline $24 \mathrm{~h}$ & $1(2)$ & $4(10)$ \\
\hline $48 \mathrm{~h}$ & $0(0)$ & $0(0)$ \\
\hline $72 \mathrm{~h}$ & $0(0)$ & $0(0)$ \\
\hline $96 \mathrm{~h}$ & $0(0)$ & $0(0)$ \\
\hline PHHPS $1:$ & & $0(0)$ \\
\hline $0 \mathrm{~h}$ & $0(0)$ & $0(0)$ \\
\hline $1 \mathrm{~h}$ & $0(0)$ & $4(10)$ \\
\hline $8 \mathrm{~h}$ & $2(5)$ & $6(15)$ \\
\hline $20 \mathrm{~h}$ & $1(2)$ & $16(40)$ \\
\hline $24 \mathrm{~h}$ & $5(12)$ & $0(0)$ \\
\hline $48 \mathrm{~h}$ & $0(0)$ & $0(0)$ \\
\hline $72 \mathrm{~h}$ & $0(0)$ & $13(33)$ \\
\hline $96 \mathrm{~h}$ & $10(24)$ & $P$ \\
\hline
\end{tabular}

$n$ - number of patients, NRS - Numeric Rating Scale, PHHPS - Prince Henry Hospital Pain Score.

is achieved by placing a curved steel bar under the sternum $[13,14]$. Severe postoperative pain is caused by the sharp deflection of the sternum and the parasternal parts of the ribs. Respiratory movements increase the pain, and 
A

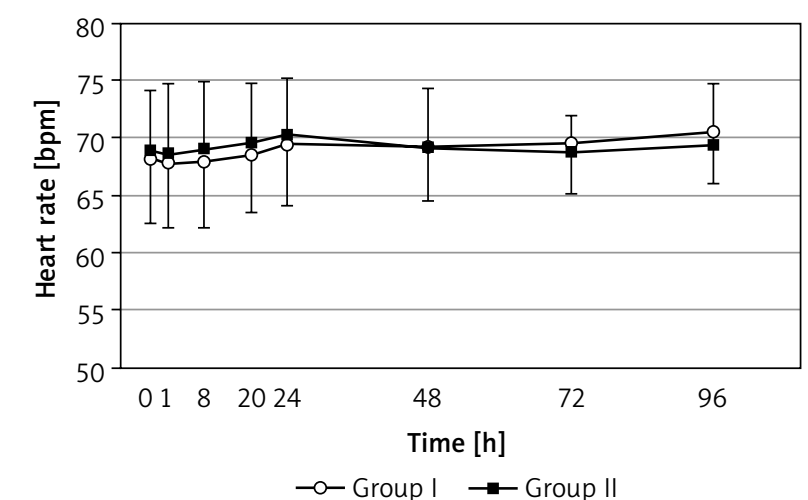

B

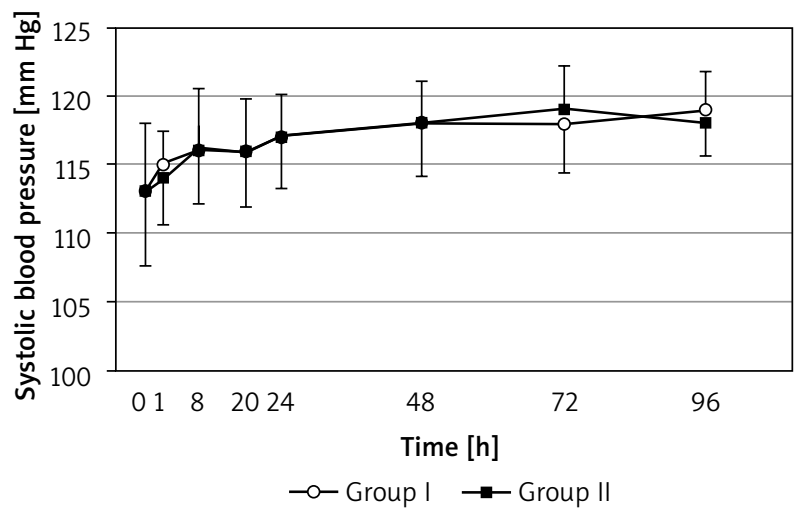

Fig. 1. Heart rate (A) and systolic blood pressure (B) in the postoperative period

Table III. Frequency of side effects in the postoperative period

\begin{tabular}{lcc} 
Side effects & $\begin{array}{c}\text { Group R }(n=41) \\
n(\%)\end{array}$ & $\begin{array}{c}\text { Group B }(n=40) \\
n(\%)\end{array}$ \\
Nausea & $3(7)$ & $3(8)$ \\
\hline Vomiting & $1(2)$ & $1(2)$ \\
\hline Bradycardia (60 bpm) & $2(5)$ & $3(7)$ \\
\hline
\end{tabular}

$n$ - number of patients, bpm - beats per minute.

therefore pain stimuli arriving from the operating field are particularly intense $[15,16]$ and sometimes very difficult to control $[8,17]$.

In contrast to bilateral thoracic paravertebral blockade recently suggested to avoid possible permanent neurological injury associated with thoracic epidural analgesia for the Nuss procedure $[18,19]$, still many groups of authors recommend a multimodal approach with thoracic epidural analgesia continuous infusion of local anesthetics (usually $0.125 \%$ bupivacaine solution) with an opioid, and if necessary supplemented with intravenous opioids or non-steroidal anti-inflammatory drugs $[12,20]$. In our study, low concentrations of local anesthetics were used, previously not reported in the medical literature for epidural analgesia in children.

The studied population was homogeneous with a mean age of 15 years. It is believed that older children and adults are more likely to suffer pain in the postoperative period. This was confirmed by Coln et al. [17], who studied the postoperative course of the Nuss procedure in adults between 19 and 46 years of age. It is difficult to explain why the pain scores are lower in our study than in that study. Approximately $40-45 \%$ of the studied patients were classified as ASA II due to either mitral valve prolapse, aortic valve insufficiency, or pulmonary valve insufficiency as well as coexisting asthma.

In the treatment of postoperative pain using epidural infusions, the lowest effective concentrations of local analgesics should be used. The aim is to achieve greater selectivity of the blockade, which allows the frequency of complications (mainly hemodynamic) to be lowered, with comparable efficacy. Using low concentrations can also significantly increase the volume of administered solutions, which helps to provide analgesia within the respective dermatomes, increasing the global effectiveness of analgesia. We were able to provide sufficient analgesia in the vast majority of patients $(93.8 \%)$ with a $0.0625 \%$ solution of bupivacaine and a $0.1 \%$ solution of ropivacaine.

Similar studies were carried out using ropivacaine. Lee et al. [21] found that the addition of $1 \mu \mathrm{g} / \mathrm{ml}$ fentanyl to $0.1 \%$ ropivacaine solution enhances analgesia without the occurrence of side effects associated with opioid administration. Goldstein et al. [22] stated that co-analgesics and various additional analgesics, administered as a "rescue" medication during epidural analgesia, should become part of routine postoperative care. These data are consistent with the results of our research.

There are a few ways to calculate doses in epidural analgesia in children described in the literature. Canovas Martinez et al. [23] suggested that for thoracic epidural analgesia, 0.02 to $0.04 \mathrm{ml} / \mathrm{kg}$ per segment should be administered, depending on age. Another dosing regimen is based on the Schulte-Steinberg rule, where the volume of local anesthetic is expressed in milliliters per segment and is equal to $10 \%$ of the child's age in years. In our study, we followed the principle of minimum effective doses. In the calculations of the volume of local anesthetic, we decided to use the Bromage formula, which has been tested in a pilot group and then locally modified. We aimed to calculate the required dose, obtaining the lowest possible concentrations of local analgesics. As a result, for most patients in our study the estimated mean daily dose of bupivacaine and ropivacaine was low: $105 \mathrm{mg}$ and $84 \mathrm{mg}$, respectively.

Another issue is the incidence of postoperative nausea and vomiting. Towell et al. [24] noted that in the group receiving $0.1 \%$ bupivacaine with $10 \mathrm{mg} / \mathrm{ml}$ fentanyl nausea and vomiting occurred more frequently than in the group receiving $0.1 \%$ bupivacaine with $5 \mathrm{mg} / \mathrm{ml}$ fentanyl. In the study conducted by Lejus et al. [25] in a group of 348 pediatric patients receiving epidural analgesia after multiple types of surgery, the incidence of nausea or vomiting was approximately $14 \%$, similarly to Frawley et al. [5], who found that among a pediatric population anesthetized particularly for the Nuss procedure managed with thoracic epidural combined with intravenous morphine infusion as 
a postoperative pain regimen, the PONV rate was $16.6 \%$. In our study, the incidence of nausea and vomiting was lower, around $7-8 \%$ and $2 \%$, respectively, in groups $R$ and $B$. This difference may be explained by the fact of lower doses of epidural opioids and no need for subcutaneous administration of morphine.

The consumption of supplementary analgesics was also a subject of analysis, as a part of regional analgesia effectiveness assessment. There was no significant difference between groups $R$ and $B$ in mean daily consumption of non-opioid analgesics. The majority of these drugs were used on the second postoperative day. McBride et al. [16], who studied patients with thoracic epidural analgesia after the Nuss procedure, found that $53 \%$ of the individuals did not require additional analgesics. Molik et al. [3] found a significantly lower effectiveness of epidural infusion, since only $11 \%$ of children did not require additional analgesia. Our study is therefore more comparable to the results presented by McBride et al. [16], since in our material only $18 \%$ of children required additional doses of non-opioid analgesic drugs.

We are well aware of potential limitations of this study. The most important of them stems from the fact that our analysis was underpowered. As the Nuss procedure is performed quite rarely, collecting an adequately powered sample in a single center is a challenge. Therefore, this study was designed as a non-inferiority rather than a superiority trial. Furthermore, because the sample size was too small, we were unable to control the postoperative pain scores for patients' heart rate and systolic blood pressure, or determine the spatial correlation between the repeated measures.

\section{Conclusions}

The results of our study indicate that our routine postoperative pain treatment regimen for patients after the Nuss procedure is safe and provides adequate pain control. We also confirmed that ropivacaine in $0.1 \%$ solution as well as a $0.0625 \%$ solution of bupivacaine can provide sufficient analgesia. We conclude that $0.1 \%$ epidural ropivacaine has no advantage over $0.0625 \%$ epidural bupivacaine in relieving acute postoperative pain after the Nuss procedure.

\section{Disclosure}

Authors report no conflict of interest.

\section{References}

1. Hebra A, Calder BW, Lesher A. Minimally invasive repair of pectus excavatum. J Vis Surg 2016; 2: 73.

2. Obermeyer RJ, Goretsky MJ. Chest wall deformities in pediatric surgery. Surg Clin North Am 2012; 92: 669-684.

3. Molik KA, Engum SA, Rescorla FJ, West KW, Scherer LR, Grosfeld JL. Pectus excavatum repair: experience with standard and minimal invasive techniques. J Pediatr Surg 2001; 36: 324-328.
4. Nuss D, Obermeyer RJ, Kelly RE. Nuss bar procedure: past, present and future. Ann Cardiothorac Surg 2016; 5: 422-433.

5. Frawley G, Frawley J, Crameri J. A review of anesthetic techniques and outcomes following minimally invasive repair of pectus excavatum (Nuss procedure). Paediatr Anaesth 2016; 26: 1082-1090.

6. Stroud AM, Tulanont DD, Coates TE, Goodney PP, Croitoru DP. Epidural an algesia versus intravenous patient-controlled analgesia following minimally invasive pectus excavatum repair: a systematic review and meta-analysis. J Pediatr Surg 2014; 49: 798-806.

7. Weber T, Mätzl J, Rokitansky A, Klimscha W, Neumann K, Deusch E; Medical Research Society. Superior postoperative pain relief with thoracic epidural analgesia versus intravenous patient-controlled analgesia after minimally invasive pectus excavatum repair. J Thorac Cardiovasc Surg 2007; 134: 865-870.

8. Beltran R, Veneziano G, Bhalla T, Kenney B, Tumin D, Bissonnette B, Tobias JD. Postoperative pain management in patients undergoing thoracoscopic repair of pectus excavatum: a retrospective analysis of opioid consumption and adverse effects in adolescents. Saudi J Anaesth 2017; 11: 427 431

9. Brockway MS, Bannister J, McClure JH, McKeown D, Wildsmith JA. Comparison of extradural ropivacaine and bupivacaine. Br J Anaesth 1991; 66: 31-37.

10. Morton NS. Ropivacaine in children. Br J Anaesth 2000; 85: 344-346.

11. Graf BM, Zausig Y, Zink W. Current status and clinical relevance of studies of minimum local-anaesthetic concentration (MLAC). Curr Opin Anaesthesiol 2005; 18: 241-245.

12. Walaszczyk M, Knapik P, Misiolek H, Korlacki W. Epidural and opioid an algesia following the Nuss procedure. Med Sci Monit 2011; 17: PH81-PH86.

13. Fortmann C, Göen T, Krüger M, Ure BM, Petersen C, Kübler JF. Trace metal release after minimally-invasive repair of pectus excavatum. PLoS One 2017; 12: e0186323.

14. Protopapas AD, Athanasiou T. Peri-operative data on the Nuss procedure in children with pectus excavatum: independent survey of the first 20 years' data. J Cardiothorac Surg 2008; 3: 40

15. Inge TH, Owings E, Blewett CJ, Baldwin CE, Cain WS, Hardin W, Georgeson KE. Reduced hospitalization cost for patients with pectus excavatum treated using minimally invasive surgery. Surg Endosc 2003; 17: 1609-1613.

16. McBride WJ, Dicker R, Abajian JC, Vane DW. Continuous thoracic epidural infusions for postoperative analgesia after pectus deformity repair. J Pediatr Surg 1996; 31: 105-107.

17. Coln D, Gunning T, Ramsay M, Swygert T, Vera R. Early experience with the Nuss minimally invasive correction of pectus excavatum in adults. World J Surg 2002; 26: 1217-1221.

18. Hall Burton DM, Boretsky KR. A comparison of paravertebral nerve block catheters and thoracic epidural catheters for postoperative analgesia following the Nuss procedure for pectus excavatum repair. Paediatr Anaesth 2014; 24: 516-520.

19. Richardson J, Lönnqvist PA, Naja Z. Bilateral thoracic paravertebral block: potential and practice. Br J Anaesth 2011; 106: 164-171.

20. Patvardhan C, Martinez G. Anaesthetic considerations for pectus repair surgery. J Vis Surg 2016; 2: 76

21. Lee WK, Yu KL, Tang CS, Lee LS, Fang HT, Au CF. Ropivacane $0.1 \%$ with or without fentanyl for epidural postoperative analgesia: a randomized, double-blind comparison. Kaohsiung J Med Sci 2003; 19: 458-463.

22. Goldstein DH, Van Den Kerkhof EG, Sherlock R, Sherlock J, Harper S. How an audit of epidural patients in a community hospital setting resulted in the development of a formal acute pain management service. Pain Res Manag 2001; 6: 16-20.

23. Canovas Martinez L, Dominguez Garcia M, Fernandez Gil N, Montes Deza A, Lopez Alonso D, Castro Mendez A. Thoracic epidural analgesia in the postoperative period of pediatric surgery for the repair of pectus excavatum and pectus carinatum. Rev Esp Anestesiol Reanim 1998; 45: 148-152.

24. Towell TJ, Maric S, Jones M, Wyatt R, Duthie DJ. Introducing ropivacaine into a department's epidural analgesic practice. Improving acute pain service practice. Clin Perform Qual Health Care 2000; 8: 217-221.

25. Lejus C, Surbled M, Schwoerer D, Renaudin M, Guillaud C, Berard L, Pinaud M. Postoperative epidural analgesia with bupivacaine and fentanyl: hourly pain assessment in 348 paediatric cases. Paediatr Anaesth 2001; 11: $327-332$. 